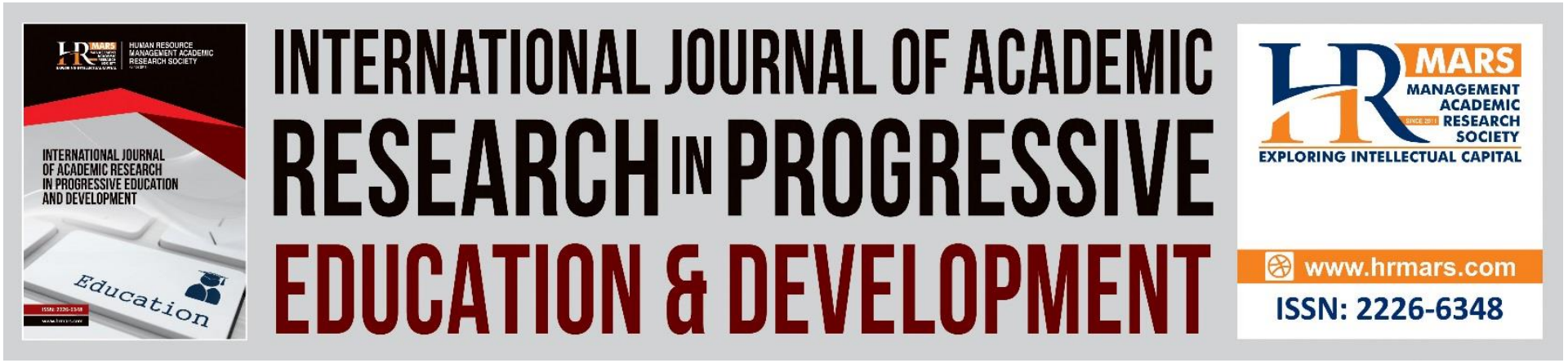

\title{
Understanding, Education, and Democratisation of Human Rights in Malaysia
}

\section{Naresh Kumar Samy, Ahmad Faisal Mahdi, Nur Hazelen Mat Rusok}

To Link this Article: http://dx.doi.org/10.6007/IJARPED/v10-i3/10662

DOI:10.6007/IJARPED/v10-i3/10662

Received: 16 June 2021, Revised: 20 July 2021, Accepted: 17 August 2021

Published Online: 28 August 2021

In-Text Citation: (Samy et al., 2021)

To Cite this Article: Samy, N. K., Mahdi, A. F., \& Rusok, N. H. M. (2021). Understanding, Education, and Democratisation of Human Rights in Malaysia. International Journal of Academic Research in Progressive Education and Development, 10(3), 295-306.

Copyright: (C) 2021 The Author(s)

Published by Human Resource Management Academic Research Society (www.hrmars.com)

This article is published under the Creative Commons Attribution (CC BY 4.0) license. Anyone may reproduce, distribute, translate and create derivative works of this article (for both commercial and non-commercial purposes), subject to full attribution to the original publication and authors. The full terms of this license may be seen

at: http://creativecommons.org/licences/by/4.0/legalcode

Vol. 10(3) 2021, Pg. 295 - 306

http://hrmars.com/index.php/pages/detail/IJARPED

JOURNAL HOMEPAGE

Full Terms \& Conditions of access and use can be found at http://hrmars.com/index.php/pages/detail/publication-ethics 


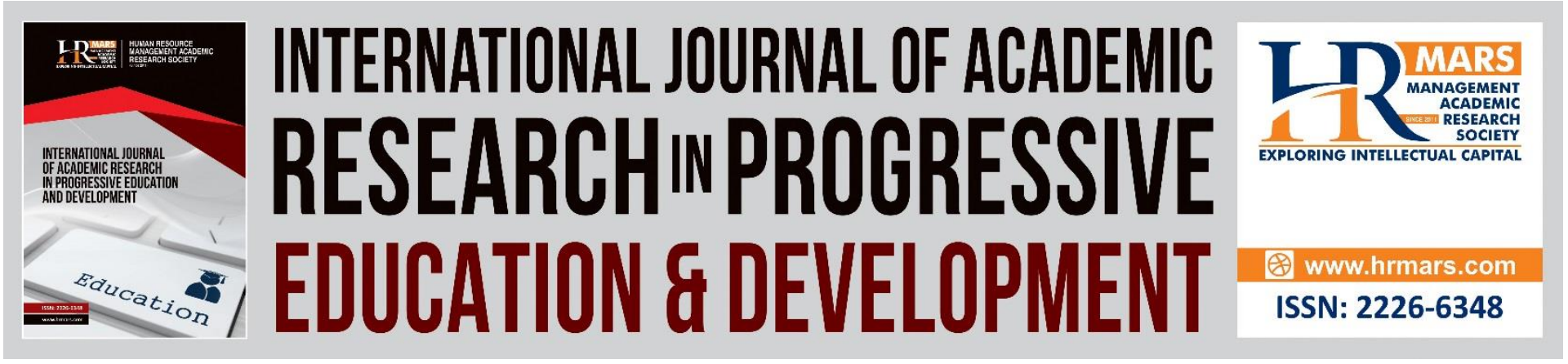

\title{
Understanding, Education, and Democratisation of Human Rights in Malaysia
}

\author{
Naresh Kumar Samy ${ }^{1}$, Ahmad Faisal Mahdi², Nur Hazelen Mat \\ Rusok $^{3}$ \\ ${ }^{1}$ Faculty of Entrepreneurship and Business, Universiti Malaysia Kelantan, ${ }^{2,}{ }^{3}$ Faculty of \\ Business and Management, Universiti Teknologi MARA, ${ }^{1}$ Faculty of Business, Management \\ and Information Technology, Asia Metropolitan University \\ Email: naresh@umk.edu.my
}

\begin{abstract}
Continuous study and reporting are critical to keeping open the possibility of realising old paradoxes, learning new methods, and leading policy adjustments that protect the human movement. This study provides baseline data to detect essential needs and gaps and compare subsequent surveys to evaluate the progress of various activities and interventions on human rights. The respondents revealed a low level of human rights knowledge. However, the majority do not perceive a conflict between human rights, religion and national culture. Researchers believe that a solid understanding of human rights is essential for any community that wishes to reverence and advocate for them, whether locally or globally. The government and other institutions concerned with human rights problems are ultimately responsible for ensuring that this occurs. Promote human rights as part of a lifelong learning process that begins at home and continues in school and extends beyond the classroom into higher education, the workplace, communities, and global society. The paper contributes to growing consciousness and understanding of the nature of everyone's duties in human rights. It helps as a foundation for studies in human rights techniques in future education.
\end{abstract}

Keywords: Awareness, Education, Human Rights, Malaysia

\section{Introduction}

Malaysia aspires to modernise its economic operations and establish a good and caring society, even though criminal offences are prevalent among the younger population. It demonstrates that the modernisation of Malaysia will go with an increase in behavioural difficulties. Perhaps increasing awareness of human rights and how violations of these rights damage one's well-being and dignity might assist reduce the occurrence of troublesome and offensive conduct. Various governmental and non-governmental organisations are working to improve public knowledge and comprehension of human rights issues via education, promotion, and constructive discussion (Amin, 2021; Hooi, 2021; Balakrishnan, 2021; Nordin \& Abdullah, 2017; Nordin et al., 2012; Soong, 2019). Human rights are of fundamental importance to democratic societies, and young people must appreciate that significance. In 
Malaysia, young people account for the vast majority of the country's population, and it is this group of people who will serve as the country's future leaders in the coming years. As a result, they should be able to make essential contributions to the progress of humanity and peace in Malaysia via expressing ideas, opinions, or suggestions that are unique to them and their communities.

Before any other elements (such as politics, economy, social, technology, legal, and environment) influence human rights, one can quantify the direct benefits of human rights awareness. Also necessary is the documentation of the learning and transfer of information from civic-based courses before acquiring skills and knowledge in the workplace. Robinson et al.(2020) believe that an excellent curriculum serves learners and society as a whole. We suggest that proactive actions on human rights awareness based on research findings and students responses assist in creating capacity for change in the short term. Respective institutions may safely modify the education programme as time passes, considering the dynamic changes in modern society. Consequently, this enhances one's comprehension in light of today's youth's knowledge of human rights besides a better understanding of these topics.

\section{Literature Review}

It is well-known that the Office of the High Commissioner for Human Rights (OHCHR) has established Guidelines for National Plans of Action for Human Rights Education in association with the United Nations Educational, Scientific, and Cultural Organization (UNESCO). It has enabled the execution of a global education programme for human rights. It stresses the advancement of knowledge and respect for others' beliefs, cultures, and opinions, with the ultimate objective of discouraging conflict and settling global peace. Indeed programmes of study should contain elements of human rights to provide learners with an appreciation of societal and international issues from human rights (Fischlin \& Nandorfy, 2007; Gerber, 2013; Robinson et al., 2020; Tibbitts \& Fernekes, 2011). Having sworn to the philosophy, principles, and standards outlined in the Universal Declaration of Human Rights (UDHR), Malaysia has undertaken regulations, ideas, and conceptions that the document embodies. Malaysia also complies with intercontinental human rights standards, as mandated by the UDHR and the Malaysian constitution. The country coordinates its human rights policies, Sustainable Development Goals, and National Human Rights Action Plan closely with key partners (Amin, 2021; Hooi, 2021; Hoon et al., 1993; Nordin \& Abdullah, 2017; Soong, 2019)

It is irrefutable that human rights are inherent rights of every human being, regardless of disparities in race, skin colour, gender, sexual orientation, linguistics, religion, socio-politics, or other communal standings. Governmental rights are the rights to interfere with and engage in the activities of governments, such as the right to vote, nominate a candidate for an election, the right to participate in state and social administration, and the right to freedom of expression, among other things. There is an increasing demand for better living standards, such as the right to education, job, a healthy and safe working environment, religion, language and culture (Gerber, 2013; Robinson et al., 2020; Tibbitts \& Fernekes, 2011). Individual and collective rights are two perspectives on human rights. Individual rights enforced by national law include life, health, education, work, voting, freedom of speech, and freedom from torture. Collective/group rights are rights granted to groups based on membership, such as women, children, and indigenous people's rights. Human rights legislation protects people 
and communities from activities that violate basic human dignity. In Hornberg (2002), the expansiveness and diversity of human rights, their link to human dignity and existence, and their intimate connection to human rights knowledge are all encompassed as part of the context of international human rights knowledge. Equality and reparation channels are a kind of universal human rights.

Higher education students must receive the right competencies about human rights, which is essential. Education on human rights is devoted to improving the general public's awareness of human rights as specified in the UDHR and other related human rights accords. Also included is the means of detecting and redressing rights violations. Tibbitts and Fernekes (2011) alluded that many UN-affiliated governmental agencies and various international organisations, national human rights organisations, and regional human rights organisations stand firmly in favour of adding human rights to the education curriculum. Gerber (2013) noted that it had not been simple maintaining interest in human rights education while also being highly dubious of the nature of human rights. The curriculum on civil rights concerns the universality of civil liberties and questions raised about whether or not the human rights framework is relevant to national and cultural legalities. Some norms might appear to conflict with human rights (Manan, 1999; Mihr, 2009). Everyone should have the opportunity to review their beliefs and realise that human rights are always in development and sometimes even clash. Universality and indivisibility are paramount to the United Nations values. Still, as part of the curriculum in a successful human rights education programme, students must grasp the ramifications of these ideas.

The establishment of a human rights education curriculum for university students is essential. This programme aims to increase the general public's knowledge of human rights as outlined in the UDHR and other relevant human rights accords. In addition, the methods for identifying and resolving rights breaches need to entrench in the educational curriculum. Several United Nations-affiliated governmental agencies and various international organisations, national human rights organisations, and regional human rights organisations have expressed strong support for the enclosure of civic rights in the educational curriculum, as noted by Tibbitts and Fernekes (2011). Keeping interested in human rights education while also being very sceptical about the nature of human rights, as Gerber (2013) observed, has not been an easy task. When discussing human rights in the classroom, it is unavoidable that issues arise regarding the widespread or global acceptance of human rights and whether or not the human rights framework is relevant to national and cultural laws in particular, which appear to be at odds with human rights. Everyone should get a chance to reexamine their ideas and recognise that human rights are constantly evolving and might even conflict with one another at times. Universality and indivisibility are fundamental to the United Nations' core ideals. Nevertheless, to succeed in human rights education, learners should understand the implications of these concepts as part of the curriculum (Amin, 2021; Bhattacharjee \& Kanagaraju, 2019; Hooi, 2021; Manan, 1999).

Despite several obstacles, many parents, educators, government officials, nongovernmental groups, and concerned members of the general public in Malaysia have all tried to spread awareness of human rights in Malaysia. Specific initiatives have been complete to ensure youngsters are not set aside from enjoying their fundamental rights to live and participate in the democratic nation's lawful activities (Bhattacharjee \& Kanagaraju, 2019; Hooi, 2021; Nordin \& Abdullah, 2017; Nordin et al., 2012; Soong, 2019). Determination how conscious the youths of Malaysia are of human rights, it is critical to research how well they 
understand the rights crucial to assess their social responsibilities and involvement in the community, which impact their future without violating the law. Each generation's individual experiences, histories, beliefs, and demographics significantly affect the human rights issues they understand and prioritise. Human rights are inspirational, but they also have a practical application. They serve as hopes and dreams for most humans, and they enable individuals to work for them. Awareness of human rights can have far-reaching consequences. These could include changes in beliefs and attitudes, conduct changes, social justice empowerment, understanding and competence in social concerns, and solidarity across communities and nations (Robinson et al., 2020; Fishlin \& Nandorfy, 2007).

\section{Methodology}

The study's participants were final-year undergraduate students-a convenience sampling approach employed in a non-probability sampling design. Following the sample size determination table established by Krejcie and Morgan (1970), 384 respondents were select to represent the maximum sample size for a large population. The greater the sample size, the lower the error and accuracy increases (Cohen, 1992). The survey questionnaire from a study report for the UNDP project "Enhancing National Human Rights Capacity in Yemen" was adapted (Arab States-UNDP, 2014). The UNDP research report contains valuable information. The researchers realise it is essential that the study be repeated in Malaysia using identical survey items that are practical and straightforward to administer. The current study does not intend to compare the results of the Yemen samples with those from Malaysia because the study's nature does not allow for comparisons. For categorical variables, frequencies and percentages use to report the results for descriptive reasons. Besides, to discover significant differences between gender, cross-tabulations with chi-square significance testing were performed for all questions.

\section{Findings}

The respondents were 169 men (44\%) and 215 women (56\%). The majority of those who voluntarily participated and answered the survey were female. It is consistent with the reality that females have dominated higher education institutions in recent years due to the Malaysian government's investment in education free of discrimination based on gender. The majority of the respondents in this research are between the ages of 20 and 29 . They can be considered the younger adult population in Malaysia. The descriptive findings of the survey are summarised and presented at the following sessions.

\section{Human Rights Awareness}

The respondents asked about their present level of human rights awareness and the results compiled. An insufficient degree of human rights awareness is noticeable from the male (53.3\%) and female (53\%) respondents in this survey. A tiny percentage of the overall respondents said they have heard or read about human rights in general (14.1\%). The early conclusion based on the statistical data collected indicates that both male and female respondents from Malaysia who took part in this survey lacked sufficient knowledge and awareness of human rights and caused many other factors besides education. Regarding general human rights knowledge, the Chi-Square statistics revealed no statistically significant differences between males and females when comparing them based on gender: $X 2(2, N=$ $384)=.570, p=.762$. Table 1 provides a summary of the results. 
Table 1: Awareness of Human Rights

\begin{tabular}{|c|c|c|c|c|}
\hline \multirow[t]{2}{*}{ Gender } & \multicolumn{3}{|c|}{ Awareness Level } & \multirow[b]{2}{*}{ Total } \\
\hline & $\begin{array}{l}\text { Low } \\
n(\%)\end{array}$ & $\begin{array}{c}\text { Moderat } \\
\mathrm{e} \\
\mathrm{n}(\%)\end{array}$ & $\begin{array}{l}\text { High } \\
\mathrm{n}(\%)\end{array}$ & \\
\hline Male & $90(53.3)$ & $53(31.4)$ & $26(15.4)$ & 169 \\
\hline Female & $114(53.0)$ & $73(34.0)$ & 28(13.0) & 215 \\
\hline Total & $204(53.1)$ & $126(32.8$ & $54(14.1)$ & 384 \\
\hline
\end{tabular}

Note: $\mathrm{X}^{2}(2, N=384)=.570, p=.762$

\section{Human rights conflict with religion}

Male and female respondents who had heard or read about human rights expressed no concern that human rights and religion conflicted, whereas $33.3 \%$ of the overall respondents indicated they occasionally believed that human rights and religion were contrasting. Protection for religious freedom is under Malaysia's constitution. Article 11 of the Malaysian Constitution states everyone has the freedom to profess and practise their religion and the right to spread it (subject to any relevant laws prohibiting the promotion of other faiths among Muslims, as well as any other applicable laws). Additionally, Article 3 of the Constitution states that Islam is the state religion but that other religions may be freely allowed to practice in a condition of peace and cooperation alongside Islam. According to the findings of this survey, Malaysian adolescents demonstrated religious tolerance. They appreciated that every person's rights receive great attention within legal provisions in its Federal Constitution. When comparing men and women, the Chi-Square statistics revealed no statistically significant variations in the general level of human rights knowledge, with $\mathrm{X} 2$ $(1, N=384)=.338, p=.561$ for gender differences. The findings are in Table 2 .

Table 2: Human Rights Compatibility with Religion

\begin{tabular}{|c|c|c|c|}
\hline \multirow{2}{*}{ Gender } & \multicolumn{3}{|c|}{ Conflict-Religion } \\
\cline { 2 - 4 } & $\begin{array}{c}\text { Never } \\
\mathrm{n}(\%)\end{array}$ & $\begin{array}{c}\text { Sometimes } \\
\mathrm{n}(\%)\end{array}$ & Total \\
\hline Male & $110(65.1)$ & $59(34.9)$ & 169 \\
\hline Female & $146(67.9)$ & $69(32.1)$ & 215 \\
\hline Total & $256(66.7)$ & $128(33.3)$ & 384 \\
\hline
\end{tabular}

Note: $\mathrm{X}^{2}(1, N=384)=.338, p=.561$

\section{Human rights conflicts with national culture}

Over the years, Malays, Chinese, Indians, and various other ethnic groups have coexisted peacefully in Malaysia, effectively blending Malaysian culture while maintaining religious tolerance and harmony among all religions. It is possible that the constitution of Malaysia, which protects the rights of all Malaysian citizens regardless of their religious affiliation or ethnicity, has inadvertently pushed Malaysians to live in an environment of tolerance and harmony. These have been demonstrated in the current survey, in which 82.3 per cent of both male and female respondents stated that they did not believe human rights were in contradiction with Malaysian culture (Table 3). Human rights were perceived as 
incompatible with Malaysian culture by less than 20 per cent of those who answered the survey questions. According to the results of this poll, the vast majority of the young who took part in it are sure that human rights and Malaysian cultural norms or values are not at odds with one another. As seen by the significant number of young people who participated in this survey who felt confident that human rights and Malaysian identity are not in conflict with one another, the government's policies and attitudes encouraging religious tolerance and peace may have been beneficial.

Table 3: Human Rights Compatibility with National Culture

\begin{tabular}{|c|c|c|c|c|}
\hline \multirow{2}{*}{ Gender } & \multicolumn{2}{|c|}{ Conflict-National Culture } & \multirow{2}{*}{ Total } \\
\cline { 2 - 4 } & $\begin{array}{c}\text { Never } \\
\mathrm{n}(\%)\end{array}$ & $\begin{array}{c}\text { Sometimes } \\
\mathrm{n}(\%)\end{array}$ & $\begin{array}{c}\text { Not sure } \\
\mathrm{n}(\%)\end{array}$ & \\
\hline Male & $136(80.5)$ & $32(18.9)$ & $1(0.6)$ & 169 \\
\hline Female & $180(83.7)$ & $35(16.3)$ & $0(0.0)$ & 215 \\
\hline Total & $316(82.3)$ & $67(17.4)$ & $1(0.3)$ & 384 \\
\hline
\end{tabular}

Note: $X^{2}(2, N=384)=1.76, p=.411$

\section{Education and Human Rights}

Respondents questioned their thoughts on introducing more human rights education into the Malaysian curriculum and how they felt about it. Almost all of the overall male and female respondents (95.6\%) agreed, with only a small number of respondents (4.4\%) expressing uncertainty-the whole set of results presented in Table 4.

Table 4: Human Rights and Education

\begin{tabular}{|l|c|c|c|}
\hline \multirow{2}{*}{ Gender } & \multicolumn{3}{|c|}{ Human rights - Education } \\
\cline { 2 - 4 } & $\begin{array}{c}\text { Agree } \\
\mathrm{n}(\%)\end{array}$ & $\begin{array}{c}\text { Not Sure } \\
\mathrm{n}(\%)\end{array}$ & Total \\
\hline Male & $165(97.6)$ & $4(2.4)$ & 169 \\
\hline Female & $202(94.0)$ & $13(6.0)$ & 215 \\
\hline Total & $367(95.6)$ & $17(4.4)$ & 384 \\
\hline
\end{tabular}

Note: $\mathrm{X}^{2}(1, N=384)=1.46, p=.416$

\section{Human Rights Ratings}

Political, civil, economic, and social rights, among other things, were assessed in the survey using a series of questions designed to determine their relative importance to respondents. Respondents requested to evaluate the significance of each of these rights, indicating whether they thought it was "very important" or "moderately important". According to the findings, virtually every responder to this research valued social and employment rights. Table 5 summarises the descriptive data from the 32 items clustered into five. The respondents tend to consider all categories of human rights extremely essential, with percentages ranging from 51.82 to 99.22 in favour of each type. Ten items scored more than 90 per cent because the respondents deem it highly significant. Three issues that received high marks were the right to life (99.22\%), access to health services (97.66\%), and protection against cruel, inhuman, or degrading treatment $(96.88 \%)$. 
Table 5: Human Rights: Level of Importance $(n=384)$

\begin{tabular}{|c|c|c|c|c|}
\hline \multirow[t]{2}{*}{ Items } & \multicolumn{2}{|c|}{$\begin{array}{l}\text { Very } \\
\text { Important }\end{array}$} & \multicolumn{2}{|c|}{$\begin{array}{l}\text { Moderately } \\
\text { Important }\end{array}$} \\
\hline & $\mathbf{n}$ & $\%$ & $\mathrm{n}$ & $\%$ \\
\hline General Human Rights Concerns* & 370 & 96.22 & 15 & 3.78 \\
\hline Access to health service & 375 & 97.66 & 9 & 2.34 \\
\hline Equal access to government services & 371 & 96.61 & 13 & 3.39 \\
\hline Access to education & 368 & 95.83 & 16 & 4.17 \\
\hline Right to adequate/decent standard of living & 364 & 94.79 & 20 & 5.21 \\
\hline Civil Rights Relating to the Administration of Justice* & 348 & 90.52 & 36 & 9.48 \\
\hline Equality before the law & 372 & 96.88 & 12 & 3.13 \\
\hline Protection from inhuman or degrading punishment & 372 & 96.88 & 12 & 3.13 \\
\hline Protection from arbitrary arrest & 361 & 94.01 & 23 & 5.99 \\
\hline Right to be considered innocent until proven guilty & 318 & 82.81 & 66 & 17.19 \\
\hline The right to free, fair, and public trial & 315 & 82.03 & 69 & 17.97 \\
\hline Attitudes Regarding Economic Rights* & 290 & 75.52 & 94 & 24.48 \\
\hline Right to work & 360 & 93.75 & 24 & 6.25 \\
\hline Right to fair and equal pay for equal work & 267 & 69.53 & 117 & 30.47 \\
\hline Right to own property & 243 & 63.28 & 141 & 36.72 \\
\hline General Attitudes Regarding Civil Rights* & 286 & 74.54 & 98 & 25.46 \\
\hline Right to life & 381 & 99.22 & 3 & 0.78 \\
\hline $\begin{array}{l}\text { Freedom of assembly including the right to peacefully } \\
\text { protest, demonstrate, or strike }\end{array}$ & 312 & 81.25 & 72 & 18.75 \\
\hline Freedom of Expression and opinion & 306 & 79.69 & 78 & 20.31 \\
\hline Right to privacy of the home, family, and correspondence & 275 & 71.61 & 109 & 28.39 \\
\hline Freedom of the press & 272 & 70.83 & 112 & 29.17 \\
\hline Freedom of movement and residence & 267 & 69.53 & 117 & 30.47 \\
\hline $\begin{array}{l}\text { Right to not be illegally transported across international } \\
\text { borders }\end{array}$ & 243 & 63.28 & 141 & 36.72 \\
\hline Right to form professional associations & 234 & 60.94 & 150 & 39.06 \\
\hline Attitudes Regarding Social Rights and Cultural Rights* & 264 & 68.84 & 120 & 31.16 \\
\hline $\begin{array}{l}\text { Rights of a child to be free from physical harm and be } \\
\text { cared }\end{array}$ & 354 & 92.19 & 30 & 7.81 \\
\hline Right to consensual marriage & 320 & 83.33 & 64 & 16.67 \\
\hline Rights of people with disabilities & 289 & 75.26 & 95 & 24.74 \\
\hline $\begin{array}{l}\text { Right to Malaysian nationality for children even if one } \\
\text { parent is not Malaysian }\end{array}$ & 267 & 69.53 & 117 & 30.47 \\
\hline $\begin{array}{l}\text { Equal rights of all regardless of race, skin colour, gender, } \\
\text { nationality or social origin, language, ethnicity, or } \\
\text { birthplace }\end{array}$ & 258 & 67.19 & 126 & 32.81 \\
\hline Equal rights between men and women in divorce & 255 & 66.41 & 129 & 33.59 \\
\hline The right to marry and start a family & 225 & 58.59 & 159 & 41.41 \\
\hline Equality of men and women in all rights & 212 & 55.21 & 172 & 44.79 \\
\hline $\begin{array}{l}\text { Right to Malaysian nationality for a Malaysian who has } \\
\text { married a foreigner }\end{array}$ & 199 & 51.82 & 185 & 48.18 \\
\hline Attitudes regarding Political Rights* & 240 & 62.50 & 144 & 37.50 \\
\hline
\end{tabular}


Right to form political parties

Right to assume a position in the government

Right to elect political leadership

Note: * Average $(\mathrm{n}, \%)$

\section{Discussion}

In an attempt to foster an atmosphere that welcomes diversity and equity while protecting from many different forms of discrimination, harassment, assault, and terrorism towards their fellow community, educational institutions advised designing surroundings that do just that. Integrating themes linked with human rights education, such as civic engagement, cross-cultural understanding, and sustainability education, in the educational eco-system is essential. In addition, educational programmes should make progress to meet the unique requirements of students, such as those who are First Nations, native, in a vulnerable position, recent immigrants and students who speak a minority language, among other groups. Insights into human rights education help develop a comprehensive, rightsbased approach that incorporates "human rights through education". It will promote an education process that ensures all components and the education procedures themselves, such as lesson plans, educational resources, techniques, and training, sync with human rights enlightenment. Second, "human rights in education," which guarantees that all community people can enjoy their legal human rights.

Developing a human rights learning and practise model will introduce human rights education in elementary and secondary education. It is part of the educators' responsibility to ensure that this goal is achieved within the learning community because they are the primary depositaries of the curriculum. Many aspects must be taken into consideration by educators for them to fulfil this important job properly. First and foremost, instructors are themselves individuals with legal rights. To advocate human rights education, they must first be recognised and respected for their professional standing and maintain their self-esteem. Institutional administration and strategic direction, at the same time, educational policymakers must encourage and permit educators and learners to experiment with new teaching and learning methods. It is necessary to guarantee that teachers and other educational professionals have appropriate education and professional development. Human rights education should be embedded in early childhood education, endure through elementary and secondary educational establishments, and expand beyond the confines of the classroom into higher learning, work, and engage in all aspects of civil society for the duration of one's life.

Gadgets and technical equipment used by the current generation have become an inseparable part of their daily routines and activities. They are more aware of all the material and debates they may become involved in due to their use of social media. These young people will have the unique chance to share their expertise by publishing items on Facebook, Twitter, Instagram, and other comparable social media platforms. Society, businesses, and government agencies should use this opportunity to draw attention to human rights issues, themes, and policies. Giving access to social media tools may encourage people to talk about human rights on social media. Continuous attention on human rights could be reached by Involving young people in human rights activities through organising debates, giving out human rights prizes, putting on theatrical plays, conducting campaigns, setting up forums, teaching, discussing, conducting workshops, and hosting conferences. 
A more race-conscious society is critical to preventing discrimination and prejudice. It will be possible to establish a mentality that values religious tolerance if this mindset develops at a very young age. Repeated efforts should help rid society of stigmas and discriminatory attitudes and practices directed toward the following groups: foreigners, people of different races, or people of other religions. One can volunteer at organisations that assist those in these groups.

In light of the explanations provided in the preceding section on the fundamental features of the present younger generation, it is clear that this generation has access to various human rights concerns through the use of online portals and social media. They have a great deal of valuable information about current human rights issues, but their credibility is unclear. This generation could refer to old or distorted information or may be pointing to new sources of knowledge. Thus, the young nations must receive the correct information by looking through the proper channels. In Malaysia, the laws are associations with preserving existing traditions and precedents and maintaining stability and continuity. The role of law in Malaysia is to safeguard human rights and the common good while maintaining order. Society at large and the younger generation should take an active part in their own educational and awareness-creating endeavours by using all the application materials accessible on the legislation that controls their rights. Through conscious recognition of human rights, values and attitudes can transform behaviour and social justice empowerment. Sympathy and solidarity across issues, communities, and nations can also be evolving. And, through knowledge and analytical skills, the general population will help make changes in the world.

\section{Conclusion}

The survey revealed that many Malaysian youths are somewhat unaware of the application and violation of human rights. While Malaysian laws and institutions exist and, in many situations, serve to protect the nation, younger nations have to be aware of where they may go for assistance when it comes to concerns of individual rights. Thus, education on human rights is vital to raise awareness about their fundamental rights. The study's findings underline the need for a more active and effective human rights education programme to guarantee that human rights issues are adequately circulated and uplift Malaysia's youths. Given that virtually all of the respondents to the research highly favour the notion of institutionalising learning about human rights in education curriculums throughout the country, such an effort would almost certainly be broadly in support. Indeed, with the effective execution of a human rights education programme, the nation's peace and security are achieved.

In governing society conduct, the law must be recognised and practised by the people. Law is normative only if it is base on general societal rules and practices. In dealing with today's vocal and demanding younger generation, outdated laws must revoke and replace with more practical and rational legislation. It is undeniable that the government has made efforts to amend existing laws and create new ones to protect the rights of everyone. Many regulations will be examined, changed, and updated to reflect modern society's developments before recommending an appropriate strategy for the present generation, exploring people's nature and features by respective entities in power. Human rights do not require humans to act how they choose. It has control mechanisms, and its domestic law incorporation is subjective. Many nations do not universally recognise it since perceived as a 
unique and sensitive notion. To educate the present generation, they must first understand their fundamental rights as citizens. The constitution ponders social rights that vary by nation and age. Constitutional law resolves ethnic, religious, linguistic, and geographic issues. In 1957, Malayan authorities promoted an inclusive attitude and appreciated the cultural variety inside the country, this continuous to date. Human rights issues are debatable across the globe. Constant research and reporting are essential to unlearn ancient paradoxes, learn best practices, and guide remodelling laws that shield humans movements. Investing in the struggle to end human rights abuses and promote a just society for all human beings is a necessary component to eliminate human rights abuses in the long run and secure justice for all people.

\section{Acknowledgements}

The authors want to express gratitude to all the respondents who have generously contributed to this study funded by Saramedia Global Sdn Bhd, Sarawak, Malaysia.

\section{References}

Amin, A. M. (2021). Human rights the Malaysian way. https://www.nst.com.my/opinion/columnists/2021/01/659519/human-rightsmalaysian-way

Arab States-UNDP. (2014). Enhancing National Human Rights Capacity in Yemen. https://www.arabstates.undp.org/content/rbas/en/home/library/Dem_Gov/humanrights-public-awareness-survey-in-yemen.html

Bhattacharjee, R. B., \& Kanagaraju, S. (2019). Politics and Policy: Human rights apply to everyone. The Edge Malaysia. https://www.theedgemarkets.com/article/politicsand-policy-human-rights-apply-everyone

Cohen, J. (1992). Statistical Power Analysis. Current Directions in Psychological Science, 1(3), 98-101. https://doi.org/10.1111/1467-8721.ep10768783

Fischlin, D., \& Nandorfy, M. (2007). The concise guide to global human rights. Montreal: Black RoseBooks

Gerber, P. (2013). Understanding Human Rights: Educational Challenges for the Future. Cheltenham, U.K.: Edward Elgar Publishing.

Hoon, C. L., Fang, J. T. Y., Bucher, S., Basiran, N., Hussin, N. I., \& Boyman, S. N. (1993). The Best Practices of Human Rights (ATHAM) Programme in Selected Secondary Schools in Malaysia. Journal of International and Comparative Education, 2(1): 31-43. https://doi.org/10.14425/00.45.73

Hooi, K. Y. (2021). How can human rights education address and eradicate racism?.sinchew. https://www.sinchew.com.my/content/content_2445524.html

Hornberg, S. (2002). Human Rights Education as an Integral Part of General Education. International Review of Education, 48 (3-4), 187-198. https://doi.org/10.1023/A:1020330131832

Krejcie, R. V., \& Morgan, D. W. (1970). Determining Sample Size for Research Activities. Educational and Psychological Measurement, 30(3), 607610. https://doi.org/10.1177/001316447003000308

Manan, W. (1999). A Nation in Distress: Human Rights, Authoritarianism, and Asian Values in Malaysia. Sojourn: Journal of Social Issues in Southeast Asia, 14(2), 359-381. http://www.jstor.org/stable/41057001 
Mihr, A. (2009) Global human rights awareness, education and democratization. Journal of Human Rights, 8(2): 177-189. https://doi.org/10.1080/14754830902939080

Nordin, R., \& Abdullah, A. R. (2017). Human rights, its scope and application: An empirical analysis of future human rights advocates in Malaysia. Pertanika Journal of Social Sciences and Humanities, 25 (2): $741-760$.

Nordin, R., Shapiee, R., Suhor, S., Yusof, A. R. M., Muhamad, M. M. (2012). Designing Human Rights Subject Based on Students' Need. Procedia - Social and Behavioral Sciences, 59: 715-722. https://doi.org/10.1016/j.sbspro.2012.09.336.

Robinson, C., Phillips, L., \& Quennerstedt,' A. (2020). Human rights education: developing a theoretical understanding of teachers' responsibilities. Education Review, 72(2): 220241. https://doi.org/10.1080/00131911.2018.1495182

Soong, K. K. (2019). Suaram - 30 years of defending human rights in Malaysia. Malaysiakini. https://www.malaysiakini.com/news/502474

Tibbitts, F., \& Fernekes, W. R. (2011). Human rights education. In S. Totten \& J. E. Pedersen (Eds.), Teaching and studying social issues: Major programs and approaches (pp. 87117). I.A.P. Information Age Publishing. 